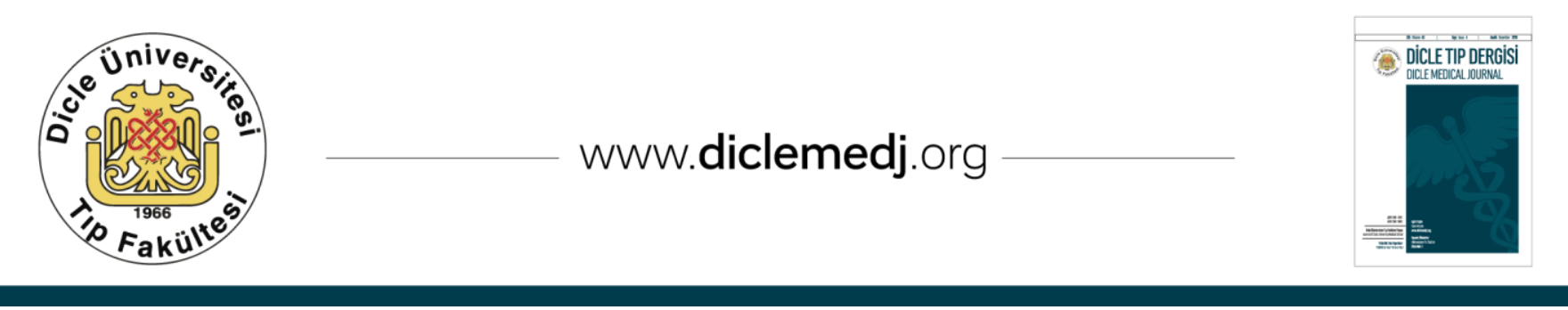

\title{
Akut Kolesistit Tanısında İnflamasyon Belirteçlerinden Nötrofil- lenfosit ve Trombosit-lenfosit Oranlarının C-reaktif protein Düzeyine Üstünlüğü Var mı?
}

\author{
Feridun Suat Gökçe1', Aylin Hande Gökçe² \\ 1 Balıklı Rum Hastanesi Genel cerrahi ABD. Zeytinburnu/ İstanbul, Türkiye ORCID: 0000-0001-8597-5787 \\ 2 İstanbul Atlas Üniversitesi Tıp Fakültesi Genel cerrahi ABD. Bagcllar/İstanbul, Türkiye ORCID: 0000-0003-1908-2889
}

Geliş: 15.05.2019; Revizyon: 16.09.2019; Kabul Tarihi: 23.09.2019

\section{$\ddot{0} \mathbf{z}$}

Amaç: Akut kolesistit acil servis ve genel cerrahi polikliniklerinde sık tanı alan hastalıklardandır. İnflamasyon derecesi hastalığın morbidite ve mortalitesi üzerine etkilidir. Bu çalışmada inflamasyon derecesini ölçmede; nötrofil-lenfosit oranı, trombosit-lenfosit oranı ve ortalama trombosit hacmi düzeyini klasik inflamasyon belirteçleriyle karşılaştırmak ve hangi değerlerin daha anlamlı olduğunu değerlendirmek istedik.

Yöntemler: Kliniğimizde Haziran 2012 ve Aralık 2017 tarihleri arasında yapılan kolesistektomi olguları retrospektif olarak incelendi. Çalışmaya alınan olgular; patoloji sonuçlarına göre akut kolesistit olan olgular grup 1, akut kolesistit olmayan olgular ise grup 2 olarak ayrıldı. Çalıșmada gruplar arası yatış süreleri, C-Reaktif Protein (CRP), lökosit değerleri, nötrofil-lenfosit oranı (NLO), trombosit-lenfosit oranı (PLO), kırmızı kan hücre dağılımı (RDW) ve ortalama trombosit hacmi düzeyleri (MPV) karşılaştırıldı.

Bulgular: Grup 1 deki olguların hastanede yatış süresi grup 2 ye göre istatistiksel açıdan anlamlı düzeyde daha uzundu ( $p<0.001$ ). Gruplar arası MPV ve RDW değerleri arasında anlamlı fark saptanmadı (sırasıyla; $p=0.128, p=0,707$ ). Grup 1'de NLO, PLO, lökosit ve CRP değerleri grup 2 ye göre istatistiksel olarak anlamlı düzeyde yüksek saptandı ( hepsi; $\mathrm{p}<0.001)$.

Sonuç: Çalışmamızda, akut kolesistit tanısında RDW ve MPV değerlerini, inflamasyon belirteci olarak anlamlı bulmadık. Akut kolesistitte, inflamasyon derecesini saptamada; NLO ve PLO' nin rutinde kullanılan tetkikler olan lökosit ve CRP değeri kadar anlamlı olduğu söylenebilir.

Anahtar kelimeler: Akut kolesistit, Lökositoz, C-reaktif protein, Kolelitiazis, inflamasyon.

DOI: 10.5798/dicletip

Yazışma Adresi / Correspondence Aylin Hande Gokce, İstanbul Atlas Tıp Fakültesi Genel cerrahi ABD. Barbaros mahallesi Gunesli post code: 34010 Bagcllar/İstanbul, Türkiye e-mail: ahgokce79@hotmail.com 


\title{
Is C-reactive Protein a Superior Marker of Inflammation over the Neutrophil/Lymphocyte Ratio or Platelet/Lymphocyte Ratio in Acute Cholecystitis?
}

\begin{abstract}
Objective: Acute cholecystitis is one of the common conditions encountered in emergency services and general surgery outpatient clinics. Survival and mortality rates positively correlate with the severity of inflammation. In this study, we aimed to compare established markers of inflammation to the neutrophil/lymphocyte ratio, platelet/lymphocyte ratio and the mean platelet volume and to assess which were the most clinically relevant.

Methods: Patients who underwent cholecystectomy in our clinic between June 2012 and June 2017 were retrospectively reviewed. Study subjects were classified into two groups: Group 1, patients with acute cholecystitis and Group 2, patients without acute cholecystitis. Two groups were compared to each other in the length of hospital stay, CRP concentrations, leukocyte counts, neutrophil to lymphocyte ratio (NLR), platelet to lymphocyte ratio (PLR), red blood cell distribution width, and the mean platelet volume.

Results: The length of hospital stay was significantly longer in the Group 1 compared to the Group 2 (p<0.001). No significant differences were found between the groups in the MPV and RDW $(p=0.128$ and $p=0.707$, respectively). The NLR, PLR,leukocyte and C-reactive protein were statistically significantly higher in the Group 1 compared to the Group 2 ( all; p<0.001).

Conclusion: Our study failed to demonstrate clinical relevance of RDW and MPV values as inflammation markers. We would like to emphasize that the NLR and PLR may be at least as helpful as other routine tests in determining the severity of inflammation.
\end{abstract}

Keywords: Acute cholecystitis,Leukocytosis, C reactive protein, Cholelithiasis, Inflammation.

\section{GİRIS}

Akut kolesistit, acil servise başvuru nedeni olan altıncı sıradaki sindirim sistemi hastalı̆̆ıdır ${ }^{1}$. Yıllar geçtikçe akut kolesistit tanısıyla yatış oranı diğer hastalıklara göre artış göstermiștir². Akut kolesistitte ortalama mortalitenin \%1, yaşlılarda ise \%2-3 dolayında olduğu bildirilmiştir 3,4. Başka bir çalışmada ise; yaşlılarda mortalitenin hafif olan akut kolesistitte \%1 den az olduğu, ağır seyreden vakalarda ise \%21 lere kadar çıkabileceği belirtilmiștir5. Akut kolesistitte inflamasyon derecesini belirlemek yani hastalığın ciddiyetini saptamak çok önemlidir. Özellikle tedaviyi optimize etmek ve mortaliteyi mümkün olduğunca azaltmak için inflamasyon derecesini bilmek önemlidir ${ }^{6}$. İnflamasyon varlığını ve derecesini belirlemede ultrasonografi, manyetik rezonans gibi görüntüleme yöntemlerinin yanında C-reaktif protein (CRP), lökosit değeri (WBC) gibi laboratuvar tetkiklerinden

de faydalanmaktayı.

Tam kan sayımı; yapılması kolay, hızlı ve ucuz bir testtir. Bu testteki beyaz küre sayısı, nötrofil, lenfosit, trombosit sayısı, ortalama trombosit hacmi (MPV) gibi değerler inflamatuar belirteç olarak kullanılabilmektedir ${ }^{7} . \quad \mathrm{Bu}$ testteki bazı değerlerin oranları özellikle nötrofil-lenfosit oranı (NLO) ve trombosit-lenfosit oranı (PLO) bazı çalışmalarda inflamatuar belirteci olarak çalışılmıştır7,8. Bizim çalıșmamızda kolelitiazis olgularında akut kolesistit hastalarıyla, inflamasyon olmayanların kan tetkiklerini (WBC, CRP, RDW, MPV, NLO ve PLO) karşılaştırarak inflamasyon belirteci olarak hangi değerlerin daha anlamlı olduğunu değerlendirmek istedik. Ayrica akut kolesistitte, laparoskopik başlanan olgularda; laparoskopik bitirilenlerle, laparoskopiden açı operasyona dönülenler arasında kan değerlerinde fark olup olmadığı araştırdık. 


\section{YÖNTEMLER}

$\mathrm{Bu}$ çalışma, insanlarla yapılan biyomedikal çalışmaları düzenleyen Helsinki Bildirgesi'ne uygun olarak yapılmıştır. Retrospektif kohort yapılan araştırmanın etik kurul onayı alınmıştır (KAEK-50- Karar No: 1616). Kliniğimizde Haziran 2012 ve Aralık 2017 tarihleri arasında yapılan kolesistektomi olguları retrospektif olarak incelendi. Araştırmaya alınma kriterleri olarak kolelithiasis tanısıyla kolesistektomi planlanıp yapılan, ameliyata laparoskopik olan başlanan, perfore olmayan, preoperatif tam kan sayımı ve CRP değerleri olan 18-80 yaş arası olgular seçildi. Çalışmadan dışlanma kriterleri kolelitiazis nedeni dışında aynı seansta başka ameliyatta yapılanlar, ameliyata ilk başta açık olarak başlananlar, perfore akut kolesistit olguları, inflamasyon göstergesi olan kan değerlerinin yüksekliği akut kolesistit nedeni dişında başka nedenlerden kaynaklananlar, trombosit değerinin yüksek veya düșük olmasina neden olan kan hastalıkları, antikoagülan ilaç kullananlar, daha önce karın içi ameliyat geçirenler, safra kesesi kanseri veya başka kanseri olan olgular olarak belirlendi.

Çalışmaya alınan olgular patoloji sonuçlarına göre akut kolesistit olan olgular grup 1, akut kolesistit olmayan olgular ise grup 2 olarak ayrıldı. Çalıșmaya alınan bütün olgulara laparoskopik olarak başlanmıştı. Safra kesesinin inflamasyonuna bağlı yapışıklığı olanlar, duktus sistikusu tam ayrilamayan olgularda açık kolesistektomiye geçilmişti. Akut kolesistit olan grup 1 olgularının ameliyatları laparoskopik tamamlanamamış ve açık kolesistektomi yapılmıșsa grup 1A, laparoskopik tamamlanmışsa grup 1B olarak sinıflandırıldı.

Çalışmada gruplar arası yaş, cinsiyet, yatış süreleri, CRP, lökosit değerleri, RDW, MPV, NLO ve PLO karşılaştırıldı.

\section{İstatistik Analiz}

İstatistiksel bulgular SPSS (Statistical Package for Social Sciences, Windows, sürüm 22.0) programı ile analiz edildi. Sürekli değișkenlerin normal dağılımın test edilmesi için Kolmogorov-Smirnov testi kullanıldı. Normal dağılım gösteren sürekli değişkenler için Student testi; normal dağılım göstermeyenler için ise Mann-Whitney U testi ile karşılaştırıldı. Sürekli değişkenler standart sapma ve ortalama olarak belirtildi. Kategorik değişkenlerin karşılaştırılmasında ki-kare testi uygulandı. P değerinin 0.05 'ten az olması istatistiksel olarak anlamlı kabul edildi.

\section{BULGULAR}

Kliniğimizde Haziran 2012 ve Aralık 2017 arasında yapılan toplam 585 kolesistektomi olgusunun 476' sı çalışmaya alındı. 109 olgu ise çalışma kriterleri dışında olduğu için çalışma dışında bırakıldı. Kolesistektomi yapılan hastalarda patoloji sonucu akut olan grup 1 de 174 olgu, akut olmayan grup 2 de 302 vaka mevcuttu. Grup 1 ikiye ayrıldı. Laparoskopik olarak ameliyata başlanıp açık operasyona dönülerek kolesistektomisi tamamlanan grup $1 A^{\prime}$ da 20 olgu, laparoskopik olarak tamamlanan grup 1B'de ise 154 hasta mevcuttu.

Grup 1'in yaş ortalaması $51.7 \pm 15.6 /$ yll, grup 2 'nin ise $46.7 \pm 15.4 /$ yll olduğu görüldü. Grupların yaşları karşılaştırıldığında; akut kolesistit grubunun yaş ortalamasının diğer gruba göre belirgin yüksek olduğu saptandı ( $\mathrm{p}=0.001)$. Grup 1' in \%35,63' ü erkek, grup 2' nin $\% 26,5^{\prime}$ si erkekti ve iki grup arasında cinsiyet dağılımda istatistiksel açıdan anlamlı fark mevcuttu ( $\mathrm{p}=0.036)$. Erkek cinsiyette ameliyat sırasinda akut kolesistit olma oranı belirgin yüksekti. Yatış süreleri karşılaştırıldığında akut kolesistit grubunda belirgin uzun olduğu görüldü $(\mathrm{p}<0.001)$. Bakılan inflamatuar belirteçlerden MPV ve RDW değerleri arasında grup 1 ve 2 arasında istatistiksel fark yoktu (sirasiyla; $\mathrm{p}=0.159$, $\mathrm{p}=0.609$ ). Lökosit, CRP, NLO ve PLO ise akut kolesistit grubunda benzer istatistiksel anlamlılıkta, belirgin yüksek olarak saptandı $(\mathrm{p}<0.001)$ (Tablo 1). 
Tablo I: Grup 1 ve grup 2 nin yaș, cinsiyet, lökosit, CRP, MPV, RDW, nötrofil lenfosit oranı, trombosit lenfosit oranı ve yatış sürelerinin karşılaștırılması

\begin{tabular}{|l|c|c|c|}
\hline & $\begin{array}{c}\text { Grup 1 } \\
\text { (akut kolesistit; n:174; \%36.6) }\end{array}$ & $\begin{array}{c}\text { Grup 2 } \\
\text { (kronik kolesistit; n:302; \%63.4) }\end{array}$ & P \\
\hline Yaş & $51.7 \pm 15.6$ & $46.7 \pm 15.4$ & $\mathrm{t}=-3.375 ; \mathbf{p}=\mathbf{0 . 0 0 1}$ \\
\hline Cinsiyet (kadın/erkek) & $112 / 62$ & $222 / 80$ & $\chi^{2}=4.408 ; \mathbf{p}=\mathbf{0 . 0 3 6}$ \\
\hline Lökosit (/mm ${ }^{3}$ ) & $9.6 \pm 4$ & $7.4 \pm 2.1$ & $\mathrm{Z}=-6.68 ; \mathbf{p}<\mathbf{0 . 0 0 1}$ \\
\hline CRP (mg/L) & $25.6 \pm 55.5$ & $5.2 \pm 19.1$ & $\mathrm{Z}=-8.604 ; \mathbf{p}<\mathbf{0 . 0 0 1}$ \\
\hline MPV (fL) & $8.5 \pm 1.7$ & $8.2 \pm 1.8$ & $\mathrm{Z}=-1.408 ; p=0.159$ \\
\hline RDW (\%) & $12.7 \pm 1.7$ & $12.8 \pm 2$ & $\mathrm{Z}=-0.511 ; \mathrm{p}=0.609$ \\
\hline Nötrofil/lenfosit & $5.8 \pm 6.1$ & $1.8 \pm 0.7$ & $\mathrm{Z}=-13.308 ; \mathbf{p}<\mathbf{0 . 0 0 1}$ \\
\hline Trombosit/lenfosit & $172.3 \pm 91.1$ & $116 \pm 37.8$ & $\mathrm{Z}=-8.042 ; \mathbf{p}<\mathbf{0 . 0 0 1}$ \\
\hline Yatış süresi (gün) & $1.4 \pm 0.7$ & $1.1 \pm 0.3$ & $\mathrm{Z}=-6.269 ; \mathbf{p}<\mathbf{0 . 0 0 1}$ \\
\hline
\end{tabular}

\section{TARTIŞMA}

Akut kolesistit tanısı konan; açığa dönülen (grup 1A) ve laparoskopik tamamlanan (grup 1B) grupların değişkenleri karşılaștırıldığında; Grup $1 A^{\prime}$ nın yaş ortalaması $59.5 \pm 16.4$ /yll, grup $1 B^{\prime}$ nin yaş ortalaması $50.7 \pm 15.3 /$ yıldı. Grup $1 \mathrm{~A}^{\prime}$ nın yaş ortalamasının grup $1 \mathrm{~B}^{\prime}$ ye göre istatistiksel açıdan anlamlı derecede yüksek olduğu görüldü $(p=0.017)$. Bu iki grupta cinsiyetler açısından anlamlı fark yoktu $(p=0.154)$. Hastanede yatma süresi ise açığa dönülen grupta belirgin yüksek olarak bulundu $(\mathrm{p}<0.001)$ İnflamatuar belirteçler karşılaştırıldığında; lökosit, CRP, MPV ve NLO arasında akut kolesistit olup açığa dönülen veya laparoskopik tamamlanan hastalar arasında istatistiksel fark olmadığı görüldü (sırasiyla; $\mathrm{p}=0.938, \mathrm{p}=0.42, \mathrm{p}=0.728, \mathrm{p}=0.551$ ). Açığa dönülen grupta RDW oranı istatistiksel olarak belirgin yüksek olarak saptandı $(\mathrm{p}=0.041)$. PLO ise yine açığa dönülen akut kolesistit grubunda laparoskopik olarak tamamlanan akut kolesistit grubuna göre yüksek bulundu. Fakat bu yükseklik istatistiksel olarak sınır değerdeydi ( $\mathrm{p}=0.051$ ) (Tablo 2).
Laparoskopik kolesistektomi ameliyatlarında inflamasyon, yapışıklıklar gibi nedenlerden dolayı bazen açı operasyona dönülmektedir.

Akut kolesistitte, elektif yapılan laparoskopik kolesistektomi ameliyatlarına göre açı̆̆a geçilme oranı daha yüksektir. Kanat ve arkadaşlarının yaptıkları çalışmada akut kolesistitlerde laparoskopiden açığa geçme oranı $\% 10,3$ olarak bildirilmiștir ${ }^{9}$. Çalışmamızda olguların \%4,2 si, akut kolesistit hastalarının ise literatüre uyumlu olarak \%11,49 unda açı ameliyata dönülmüştür.

Kolelitiazis nedeniyle ameliyat edilen hastaların cinsiyetleri karşılaştırıldığında kadın hastaların oranı daha sıktır ${ }^{10}$. Ayrıca erkek hastalar kadın hastalara göre genellikle semptomlar başladığında daha geç hastaneye başvurmaktadır ${ }^{10}$. Çalışmamızda da kolesistektomi yapılan olguların \%70' i kadındı. Ameliyat ettiğimiz olguların \%36,5' i akut kolesistitti. Cinsiyete göre kadınların \%33,5' i, erkeklerin ise \%43,6' si akut kolesistitti. Kadınların \%0,3' ü erkeklerin $\% 7^{\prime}$ si, akut kolesistit olan kadın olguların \%8,9'u, erkek olguların ise \%16,1' inde açılk kolesistektomiye dönülmüștü. Bizim çalışmamızda da literatürle uyumlu olarak kolesistektomi yaptığımız 
olguların çoğu kadındı. Erkek olgularda akut kolesistit görülme oranı ve laparoskopiden açığa geçme oranı kadın hastalardan daha sık saptandl.

Tablo II: Grup 1A ve grup 1B nin yaş, cinsiyet, lökosit, CRP, MPV, RDW, nötrofil lenfosit oranı, trombosit lenfosit oranı ve yatış sürelerinin karşılaştırılması

\begin{tabular}{|c|c|c|c|}
\hline & $\begin{array}{c}\text { Grup 1A } \\
\text { Akut } \\
\text { kolesistit } \\
\text { açığa } \\
\text { dönülen } \\
\text { grup; n:20 }\end{array}$ & $\begin{array}{c}\text { Grup 1B } \\
\text { Akut kolesistit } \\
\text { laparoskopik } \\
\text { grup; n:154 }\end{array}$ & $\mathbf{P}$ \\
\hline Yaş & $59.5 \pm 16.4$ & $50.7 \pm 15.3$ & $\begin{array}{l}\mathrm{t}=-2.404 \\
\mathbf{p}=\mathbf{0 . 0 1 7}\end{array}$ \\
\hline \begin{tabular}{|l|} 
Cinsiyet \\
(kadın/erkek)
\end{tabular} & $10 / 10$ & $102 / 52$ & $\begin{aligned} \chi^{2} & =2.034 ; \\
p & =0.154\end{aligned}$ \\
\hline Lökosit (/mm³) & $9.6 \pm 3.6$ & $9.7 \pm 4$ & $\begin{array}{c}\mathrm{Z}=-0.078 \\
\mathrm{p}=0.938\end{array}$ \\
\hline CRP (mg/L) & $15.4 \pm 37$ & $27 \pm 57.5$ & $\begin{array}{c}\mathrm{Z}=-0.807 ; \\
\mathrm{p}=0.42\end{array}$ \\
\hline MPV (fL) & $8.6 \pm 2.2$ & $8.5 \pm 1.7$ & $\begin{array}{l}t=-0.348 \\
p=0.728\end{array}$ \\
\hline RDW (\%) & $13.7 \pm 2.4$ & $12.6 \pm 1.6$ & $\begin{array}{l}Z=-2.044 ; \\
\mathbf{p}=\mathbf{0 . 0 4 1}\end{array}$ \\
\hline Nötrofil/lenfosit & $7.5 \pm 6.6$ & $5.6 \pm 6$ & $\begin{array}{c}Z=-0.597 ; \\
p=0.551\end{array}$ \\
\hline $\begin{array}{l}\text { Trombosit/lenfo } \\
\text { sit }\end{array}$ & $224.5 \pm 129.1$ & $165.5 \pm 83.1$ & $\begin{array}{c}\mathrm{Z}=-1.951 ; \\
\mathrm{p}=0.051\end{array}$ \\
\hline $\begin{array}{l}\text { Yatış süresi } \\
\text { (gün) }\end{array}$ & $2 \pm 1.1$ & $1.3 \pm 0.6$ & $\begin{array}{l}Z=-3.924 ; \\
\mathbf{p}<\mathbf{0 . 0 0 1}\end{array}$ \\
\hline
\end{tabular}

Ertok ve arkadaşlarının yaptığı çalışmada kolelitiazis olgularının yaş ortalaması 46.4 \pm 16.3 , akut kolesistit saptanan hastaların yaş ortalaması $55.9 \pm 18.5$ olarak bildirilmiştir (11). Çalışmamızda da bu çalışmaya benzer olarak akut kolesistit olgularının yaş ortalaması 51.7 \pm 15.6 , akut kolesistit bulguları olmayan kolelitiazis olgularının yaş ortalaması ise $46.7 \pm 15.4$ olarak bulundu. Bu iki grup arasında yaş açısından istatistiksel açıdan anlamlı fark mevcuttu ve akut kolesistit grubunda belirgin yüksekti $\quad(\mathrm{p}<0.001)$. Çalışmamızda akut kolesistit olgularında açığa geçilen hastalarda yaş ortalaması $59.5 \pm 16.4$, laparoskopik olarak bitirilenlerde ise $50.7 \pm 15.3$ olarak saptand. İki grup arasında istatistiksel açıdan anlamlı fark mevcuttu ve açığa dönülen hastalarda belirgin yüksekti $\quad(p=0.017)$ Kolelitiazis olan olgularında yaş arttıkça akut kolesistit ve buna bağlı olarak inflamasyon düzeyinin arttığ söylenebilir. Yaşı daha ileri olan olgularda inflamasyon derecesinin ve ameliyatlarda açı̆̆a geçme oranının arttığını belirtmek istiyoruz.

Elektif şartlarda yapılan laparoskopik kolesistektomilerde hastanede yatış süresi yaklaşık 1 gündür. Akut kolesistitlerde ise hastanede yatış süresi uzayabilmektedir ${ }^{12}$. Çalışmamızda akut kolesistit nedeniyle yapılan laparoskopik kolesistektomilere göre kronik kolesistit nedeniyle yapılan laparoskopik kolesistektomilerin yatış süresi belirgin uzun olarak bulundu. Açık ameliyata dönülen akut kolesistit olgularının hastanede yatış süresi de laparoskopik olarak tamamlanan akut kolesistit hastalarına göre belirgin uzundu. $\mathrm{Bu}$ durum bize inflamasyon düzeyi arttıkça buna paralel olarak hastanede yatış süresinin uzadığını düşündürdü. $\mathrm{Bu}$ nedenle inflamasyon derecesini doğru olarak saptamanın ve bu duruma göre tedaviyi planlamanın uygun olacağını görüşündeyiz. İnflamasyonun belirgin olduğu hastalarda, bu çalışmanın konusu olmamakla birlikte, medikal tedavi ve perkütan girişimler öncelikli olarak düşünülebilir. Böylece daha uygun ve elektif şartlarda ameliyatı planlama şansımız olabilecektir.

İnflamasyonu ve derecesini saptamak birçok hastalıkta olduğu gibi akut kolesistit olgularında da çok önemlidir. $\mathrm{Bu}$ çalışmada akut faz reaktanlarından en sık kullanılan CRP ve lökosit değerlerini de araştırdık. Yazıcı ve arkadaşları yaptıkları çalışmada akut kolesistit olgularının \%57 sinde lökositoz, \%65,2' sinde ise CRP yüksekliği bildirmişlerdir. Yine bu çalışmada RDW değerinde anlamlı değişiklik saptamamışlardır ${ }^{13}$. Çalışmamızda ise akut ve kronik kolesistit karşılaştırıldığında kan lökosit 
ve CRP düzeyi akut olanlarda anlamlı derecede yüksek saptandı. Buna karşıllk lökosit ve CRP değerleri akut kolesistitte ameliyatı açık yapılanlarla, laparoskopik tamamlananlar arasında benzerdi. Çalışmamızda da MPV değerleri karşılaștırıldığında ne akut-kronik kolesistit ne de akut kolesistitlerde ameliyatı laparoskopik tamamlanan veya açığa dönülenler arasında fark bulunmadı. Sayit ve arkadaşları yaptıkları çalışmada akut kolesistit hastalarında MPV değerini normal sağlıklı bireylere göre düşük saptamışlardır ${ }^{14}$. Bununla birlikte, biz çalışmamızda akut-kronik kolesistit hastaları arasında, akut kolesistitte açığa dönülen veya kapalı bitirilen hastalar arasında MPV düzeyinde fark saptamadık.

Çalışmamızda, akut ve kronik kolesistit olguları arasinda, RDW değerlerinin karşılaştırılmasında fark bulunmadı. Bununla birlikte akut kolesistit olup açık ameliyata dönülen hastalarda ameliyatı laparoskopik olarak bitirilenlere göre RDW düzeyi belirgin yüksek olarak saptandı $(\mathrm{p}=0.041)$. Arer ve arkadaşları yaptıkları çalışmada akut kolesistit hastalarında RDW düzeyini sağlıklı bireylere göre daha düşük saptamışlardır ${ }^{15}$. Bizim çalışmamızda ise akut ve kronik kolesistit hastaları arasında RDW değerleri açısından fark bulunmadı. Bununla birlikte inflamasyon düzeyinin en fazla olduğunu kabul ettiğimiz açık kolesistektomiyle tamamlanan olgularda RDW değeri ameliyatı laparoskopik tamamlanan gruptan belirgin yüksek olarak saptandı. $\mathrm{Bu}$ sonuç açığa dönülen zor kolesistektomilerde RDW değerinin yüksek olmasının inflamasyonla orantılı olduğunu düşündürdü. $\mathrm{Bu}$ yorumun başka çalışmalarla desteklenmesi gerektiği düşüncesindeyiz.

Ertok ve arkadaşlarının yaptığı çalışmada akut kolesistitte kronik kolesistite göre NLO oranının yüksek olması anlamlı olarak bildirilmiştir ${ }^{11}$. Başka bir çalışmada ise apendektomi yapılan olgularda gangrene olanlarda kataral ve flegmönöz olan apandisitlere göre NLO' nın daha yüksek olduğu gösterilmiştir ${ }^{16}$. Ülseratif kolit ve pnömoni üzerinde yapılan çalışmalarda da NLO oranının yüksek olduğunu gösteren çalışma vardır ${ }^{17}$. NLO açısından akut kolesistitte ameliyatı açı yapılanlarla, laparoskopik tamamlananlar arasinda fark saptanmadi. Fakat akut ve kronik kolesistit karşılaştırıldığında akut olanlarda anlamlı derecede yüksek saptandı $(\mathrm{p}<0.001)$. Literatürde multipl myelom ve malignitelerde inflamasyon belirteci olarak PLO' nun yüksek olduğunu saptamış çalışmalar mevcuttur ${ }^{18,19}$. Fakat akut kolesistitte PLO'nın araştırıldığı çalışma literatürde bulunamadı. Çalışmamızda PLO yüksekliği açısından açık kolesistektomiye dönülen inflamasyon derecesi daha fazla olan akut kolesistit olguları, laparoskopik olarak bitirilen akut kolesistit olgularına göre, bütün akut kolesistit olguları ise kronik kolesistitlere göre anlamlı derecede yüksek saptandı. Bu sonuç bize NLO ve PLO'nın, akut kolesistitte, inflamasyon derecesinin belirlenmesinde alternatif belirteçler olabileceğini düşündürdü.

Çalışmamızın retrospektif ve sınırlı sayıda hasta ile yapılmış olması, radyolojik tetkiklerden yararlanmamış olmamız eksik yönlerimiz olarak söylenebilir.

Sonuç olarak; çalışmamız, akut kolesistitte, RDW ve MPV değerlerinin inflamasyon belirteci olarak anlamlı olmadığını düşündürdü. İnflamasyon belirteci olarak kullanılan CRP ve lökosit değerleri çalışmamızda da literatürle uyumlu olarak anlamlı bulundu. Daha nadir olarak dikkat edilen, hatta çoğu zaman göz ardı edilen, NLO ve PLO' nın akut kolesistitte inflamasyon belirteci olarak rutinde baktığımız CRP ve lökosit değeri kadar yol gösterici olabileceği düşüncesindeyiz. $\mathrm{Bu}$ belirteçlerin prospektif ve daha geniş hasta sayısı olan çalışmalarla incelenmesi uygun olabilir.

Çıkar Çatışması Beyanı: Yazarlar çıkar çatışması olmadığını bildirmişlerdir.

Finansal Destek: Bu çalışma her hangi bir fon tarafından desteklenmemiștir. 
Declaration of Conflicting Interests: The authors declare that they have no conflict of interest.

Financial Disclosure: No financial support was received.

\section{KAYNAKLAR}

1. Peery AF, Crockett SD, Barritt AS, et al. Burden of gastrointestinal, liver, and pancreatic diseases in the United States. Gastroenterology 2015; 149: 1731-41.

2. Andrei M. Beliaev, M.D., Neville Angelo, Michael Booth, Colleen Bergin. Evaluation of neutrophil-to-lymphocyte ratio as a potential biomarker for acute cholecystitis. Journal of Surgical Research 2017 Mar; 209: 93-101 Doi: 10.1016/j.jss.2016.09.034

3. Kimura Y, Takada T, Strasberg SM, et al. TG13 current terminology, etiology, and epidemiology of acute cholangitis and cholecystitis. J Hepatobiliary Pancreat Sci. [Review]. 2013 Jan; 20: 8-23.

4. Papadakis M, Ambe PC, Zirngibl H. Critically ill patients with acute cholecystitis are at increased risk for extensive gallbladder inflammation. World J Emerg Surg. 2015; 10: 59.

5. Lee SW, Yang SS, Chang CS, Yeh HJ. Impact of the Tokyo guidelines on the management of patients with acute calculous cholecystitis. J Gastroenterol Hepatol. 2009 Dec; 24: 1857-61.

6. Satoa N, Kinoshitaa A, Imaia N, et al. Inflammationbased prognostic scores predict disease severity in patients with acute cholecystitis. European Journal of Gastroenterology \& Hepatology 2018 Apr; 30: 484-9. Doi: 0.1097/MEG.0000000000001063

7. Balta S, Demirkol S, Unlu M, Arslan Z, Celik T. Neutrophil to lymphocyte ratio may be predict of mortality in all conditions. Br J Cancer 2013; 109: 3125-6.

8. Nazik H, Nazik S, Çoban F. nötrofil lenfosit ve platelet lenfosit oranlarının aktif behçet hastalarındaki önemi. Bozok Tip Derg 2016; 6: 33-6.

9. Kanat BH, Yur M, Girgin M, et al. The Results of Early Cholecystectomy in Acute Cholecystitis. KocaeliMJ. 2013; 2: 21-4.
10. Sözen S, Emir S, Bali İ. Laparoskopik Kolesistektomiden Açık Ameliyata Geçme Nedenleri. Int J Basic Clin Med 2014; 2: 8-13.

11. Ertok İ, Karakayalı O, Kocasaban D. Clinical Importance of Neutrophil/Lymphocyte Ratio in Differential Diagnosis of Acute Cholecystitis and Cholelithiasis. Kocaeli Medical J 2016; 5; 3: 6-11.

12. Gurusamy KS, Samraj K, Fusai G, Davidson BR. Early versus delayed laparoscopic cholecystectomy for biliary colic. Cochrane Database Syst Rev 2008;CD007196.

13. Yazıcı P, Demir U, Bozdağ E, et al. What is the effect of treatment modality on red blood cell distribution width in patients with acute cholecystitis? Ulusal Cer Derg 2015; 31: 1-4. Doi: 10.5152/UCD.2015.2803.

14. Sayit AT, Gunbey PH, Terzi Y. Is the Mean Platelet Volume in Patients with Acute Cholecystitis an Inflammatory Marker? J Clin Diagn Res. 2015 Jun; 9: TC05-7. doi: 10.7860/JCDR/2015/12028.6061.

15. Arer İM, Yabanoğlu H, Çalışkan K. Can red cell distribution width be used as a predictor of acute cholecystitis? Turk J Surg. 2017 Jun 1; 33: 76-9. doi: 10.5152/turkjsurg.2017; 3392.

16. Ishizuka M, Shimizu T, Kubota K. Neutrophil-toLymphocyte Ratio Has a Close Association With Gangrenous Appendicitis in Patients Undergoing Appendectomy. Int Surg 2012; 97: 299-304.

17. Celikbilek M, Dogan S, Ozbakır O. NeutrophilLymphocyte Ratio as a Predictor of Disease Severity in Ulcerative Colitis. Journal of Clinical Laboratory Analysis. 2013; 27: 72-6.

18. Wongrakpanich S, George G, Chaiwatcharayut W, et al. The prognostic significance of neutrophil-tolymphocyte and platelet-to-lymphocyte ratios in patients with multiple myeloma. J Clin Lab Anal. 2016; 30: 1208-13.

19. Zheng J, Cai J, Li H, et al. Neutrophil to Lymphocyte Ratio and Platelet to Lymphocyte Ratio as Prognostic Predictors for Hepatocellular Carcinoma Patients with Various Treatments: a Meta-Analysis and Systematic Review. Cell Physiol Biochem 2017; 44: 967-981. doi: $10.1159 / 000485396$. 